\title{
The Destruction and Impossible Reconstruction of Family Links in Crossing the River by Caryl Phillips
}

\section{Anne Garrait-Bourrier}

\section{(2) OpenEdition}

12 Journals

Electronic version

URL: https://journals.openedition.org/ces/4468

DOI: $10.4000 /$ ces.4468

ISSN: 2534-6695

Publisher

SEPC (Société d'études des pays du Commonwealth)

\section{Printed version}

Date of publication: 1 September 2017

Number of pages: $45-58$

ISSN: 2270-0633

\section{Electronic reference}

Anne Garrait-Bourrier, "The Destruction and Impossible Reconstruction of Family Links in Crossing the River by Caryl Phillips", Commonwealth Essays and Studies [Online], 40.1 | 2017, Online since 02 April 2021, connection on 25 January 2022. URL: http://journals.openedition.org/ces/4468 ; DOI: https:// doi.org/10.4000/ces.4468

\section{cc) (†)}

Commonwealth Essays and Studies is licensed under a Licence Creative Commons Attribution - Pas d'Utilisation Commerciale - Pas de Modification 4.0 International. 


\section{The Destruction and Impossible Reconstruction of Family Links in Crossing the River by Caryl Phillips}

This article examines questions of kinship and family in Caryl Phillips's novel Crossing the

River from the perspective of the impact of slavery on the family and on gender roles. It explores the problematic status of both the father and the mother in a system in which the Master played the role of the symbolic father and women were "de-maternalized," in other words deprived of their traditional functions as caring and protective mothers. It furthermore raises the question of gender representations, arguing that in Phillips's vision of the "Black Atlantic," women succeed in crossing borders that are emotional and psychological, while men's voyages are concrete and pragmatic. It also explores the possibility of surrogacy as an answer to the destruction of the family and suggests that in this respect also it is male bonding that dominates Phillips's vision of the diasporic community.

The novel Crossing the River published by Caryl Phillips in 1993 focuses on family links in the context of the African diaspora. It is historically admitted ${ }^{1}$ that the destruction of the family pattern was the main horrifying consequence of the Middle Passage black people had to endure throughout the centuries of slavery which followed the development of the British and European empires. Studying their destruction/reconstruction through literature is a way for Phillips to pay an emotional tribute to the millions of families shattered by slavery ("For those who crossed the river"). ${ }^{2}$

Starting his book with this alarming statement, "A desperate foolishness. The crops failed. I sold my children" (1), Phillips explores the notion of kinship through time and space in the context of the aftermath of slavery in Europe and in the United States. Family is the place where collective and cultural memory is usually transmitted through generations. When families are destroyed, this memory is then necessarily impaired. How can culture survive when memory is destroyed; are human links subverted when family no longer plays its structuring part and when memories are diluted? What kind of agency can supplement these gaps in collective memory and help the diaspora community be part of a nation again?

To try to put these questions into perspective I will first concentrate on the representations of fatherhood in the novel, then I will compare and contrast them with the portrayal of motherhood, to insist eventually on the surrogate kinships the novel reconstructs so as to fill in - though in vain - the voids left by slavery.

\section{Two opposing value systems: the African father vs the white Master}

In the context of slavery and of postcolonial studies, the image of the father is a very ambiguous one. In recent years, the field of masculinity as it was developed in the western world has generated standards and projected itself in the reproduction of social

1. See Peter Kolchin's Unfree Labor (1987), American Slavery (1993) or Eric Foner's Forever Free (1996) and Give Me Liberty (2004), to quote a few.

2. All the quotations from Crossing the River are taken from the 2006 London Vintage edition (first edition of the book by Bloomsbury Publishing, London, 1993). This epigraph is situated before the acknowledgements. 
patterns and predetermined roles - called habitus by Bourdieu (Esquisse) - based on the concepts of physical strength, authority, control and discipline as well as responsibility.

Manliness, virility, in its ethical aspect, i.e. as the essence of the vir, virtus, the point of honor (nif), the principle conservation and increase of honour, remains indissociable, tacitly at least, from physical virility, in particular through the attestations of sexual potency $[. .$.$] which are expected from a "real" man. (Domination 12)$

The powers inherent in the vision of the dominant male have structured Western representations. Contrary to these patterns, African American and Caribbean males (Caryl Phillips is from Caribbean ancestry) have experienced fatherhood - a state essential to the construction of manhood - in a very different way. As Carl N. Degler states, "It is this lack of a developed or complete family under slavery that so handicapped the Negro once slavery was ended" (172). The denial of access to the status of pater familias - and thus to this form of fatherhood associated with power - on the plantation and under the system of the "peculiar institution" was part of the erasure of black manhood for centuries. ${ }^{3}$ Phillips's representation of fatherhood is intimately related to these historical elements and challenges the traditional standards related to gender previously analyzed by Bourdieu, as Bénédicte Ledent clearly puts it:

The multiple physical and cultural passages experienced by all the characters constantly challenge the roles traditionally imposed upon them by class, race, gender or nation. As each metaphorical river-crossing leads to a new translation of the self, we are made to ponder upon the subjectivity, relativity or inadequacy of such categories. (Caryl Phillips 58)

Movement is clearly what makes boundaries and norms mobile in the novel and what makes "river-crossing" a strategy of reconstruction of identities.

Two antagonistic value systems related to fatherhood are at odds in the novel and Africa is at the crossroads between the two. Africa is the place the Blacks were forced to leave, then forced to go back to through the implementation of the resettlement project proposed by the Christian American Colonization Society in America, between 1820 and 1850. The omnipresence of Africa in the background of the novel highlights its importance in the building of a diasporic black identity. The "extended family" of imported and exported slaves - to illustrate the "selling" and "buying" activities of Captain Hamilton - is represented by the captain of the slave ship in the eponymous section "Crossing the River" as both voiceless and without any proper identity, described merely in figures and numbers, through columns and balances, as when he actually purchases the three "heroes" of the novel, who metaphorically represent a "family": "Wednesday $19^{\text {th }}$ March... [...] Approached by a quiet fellow. Bought 2 strong man boys, and a proud girl” (124).

This lack of identity through reification is attributable to the commercialization of human beings as goods and is thus to be linked to the African father and to his initial decision to sell his own children, thus threatening the future of his family bloodline by diluting it in the vastness of the Atlantic Ocean. Africa shares a part of responsibility in the silencing of its children. Not without irony does Phillips describe the pathetic experience of Nash's "repatriation" - or quest for another "pater" - to Africa under the auspices of the American Colonization Society as a doomed return to a land of the 
The Destruction and Impossible Reconstruction of Family Links in Crossing the River by Caryl Phillips

Father which no longer generates any protective fathers, as the plight of the African father shows. Phillips summarizes his own vision of black families in this way:

There are so many broken families in the black community in general, not just in the migrant community. There tends to be a preponderance of single mothers. I'm very interested in the whole question of how, on the personal level, that has emerged out of the larger development of slavery and all of those kinds of diasporan movements. There is a very commonly held theory that one of the reasons there is such a preponderance of single mothers is because of slavery, an institution which greatly disrupted the black family. (Davison 95)

In Crossing the River, Phillips expands the absence of the father to the white world and makes it a universal plague, as Captain Hamilton's letters reveal a man concerned by the future of his family and obsessed by the mysterious death of his own father, while Joyce is also trapped in a determinism of orphanhood, her diaries evoking repeatedly the death of her mother - the father being long dead - and the death of her son's father. The "preponderance of single mothers" and of orphans is the major legacy of slavery (and of war), and this plague is shared by all the people related to this heritage.

The American Colonization Society is also presented by Phillips as being responsible for having distorted the relationships between the former slaves and their "fatherland," hence, their relationship with the figure of the father. The land of the Fathers/ancestors - Africa - and the image of a protective father had long been lost and forgotten by the slaves when America, the Land of the substitute Father - the Master - expressed its wish to get rid of them. The inverted transatlantic journey proposed by the American Colonization Society raises the question of masculine identifications and through the story of Nash, Phillips addresses the way in which men of African descent had to deal with their patriarchal lineage once they returned to Africa.

The American Colonization Society shares with the "peculiar institution," more generally speaking, part of the responsibility for the weakening of the African American family and is shown as a "peculiar" as well as an ambiguous tool used to solve the "question" of blackness and eradicate the memory of slavery in America before the Civil War, at a time when the presence of free blacks on the American soil raises the issue of their citizenship and social status. The section "The Pagan Coast" plays upon these notions of paternalism and repatriation (literally), real fatherhood being illustrated here as a divine and social authority, eminently white. Edward Williams is the American Master par excellence. He has no children of his own and thus views his slaves and even ex-slaves as his own children, assimilating "possession" with love, a paternalistic attitude developed and analyzed by Peter Kolchin as typical of the last generation of Masters (just before the Civil War) and clearly represented in Nash's letters. This equivocal emotion is nothing more than a subversion of the feeling of paternity. Phillips goes a step further by making subversion look and sound like perversion by exploring the desire Williams feels for his "son" Nash and other male slaves and servants. This can be seen as a homosexual pedophile desire. Slavery is clearly presented here as a perverted system facilitating all human perversions, even the most unnatural (in one of his letters sent from Africa Nash tells him: "you who have done more to me than my natural father" [20, my emphasis], a statement which is intensely dramatic as to what it implies about the nature of their relationship). 
The Master is the absolute Father, forgiven for having destroyed the real family links of his slaves and for having taken children from their parents. Tannenbaum in Slave and Citizen argues:

Under the law of most of the Southern states there was no regard for the Negro family, no question of the right of the owner to sell his slaves separately, and no limitation upon separating husband and wife, or child from its mother. (77)

The Master is the agent of rupture and fracture. He is also the master of memory as he recreates a new so-called "family" on the plantation he rules over, and even tries to project the idea of a "black family" far from the boundaries of white society by sending his slaves back to Africa under the pretext of Christianizing the country. He is the incarnation of the dominant mythology related to fatherhood present in Nash's mind when he leaves for Africa.

The dominant motif illustrating the distortion of fatherhood in the novel is that of absenteeism. Through fiction, fatherhood is clearly related to the notion of loss, a loss transmitted as a heritage and related to specific myths. Nash is the character who experiences in his own flesh the antagonism between two different models, two representations of masculinity and fatherhood - the white one and the African one - and fiction offers him the possibility to address this dilemma and attempt to solve it.

Once in Liberia, Nash chooses not to conform to his master's pattern and builds his own reconstruction out of fracture, a reconstruction which can only be possible once he has lost his own American representation of family. Nash chooses to have three wives (60), and a great many children. This African representation of family and of manhood based on polygamy - beyond its cultural reality - can be perceived as a way for Nash to forget his Master's sexual power over him and to question the Christian values the Master embodies: a way to choose to some extent, even though the notion of choice is a relative one in the context of deportation. Polygamy cannot be perceived as a "rebellion" as such but as Nash's physical and material adaptation to African traditions. Nevertheless, even if it is not rebellious, it can be considered as a choice consciously made by Nash to assert his own personality. As a matter of fact, when he arrives in Liberia, Nash is called "Mister Williams" by the "natives" (as he calls the Africans, 18) which indicates a position of social superiority. Nash could have chosen to adopt the life style of the "dominant people" - the former slaves coming from America - and to remain blind to the life conditions of the Africans. But his growing political consciousness and empathy for the natives and his growing criticism of slavery make him an opponent to what Williams symbolizes: "To most colored men, who reside here in liberty, and would expect liberty to encompass all of Africa, this dark land of our forefathers, this American protectionism is a disgrace to our dignity and a stain on the name of our country" (41). The double use of the pronoun "our" - first related to Africa, then applied to America - indicates a clear rupture in Nash's mind and heart. His statement, a few pages later, confirms this rupture: "That my present family does not conform to what you might reasonably expect of me will no doubt disturb you" (60). This can then be read as an expression of his satisfaction in opposing the Master. The more he becomes a man again, the more distant he becomes from his "Dear father" (letter written in 1840,40). The Master is eventually contested as a father figure and as a symbol of power. That Nash chooses to create an African family is a sign of the falseness of the idea that the master can be a father. The myths of fatherhood related to slavery 
and the cultural reality of Africa are two different representations of the same ideal of fatherhood, and the space of fiction exposes the contradictions existing between these two representations. At first, Nash's "pioneering" to Africa is a religious mission and he goes to Africa as a conqueror. What he experiences in Africa is the destruction of his acquired convictions about the white mythology of fatherhood - the master is not God, and he is not the ideal Father either. His confrontation with an African reality ends up showing him that there is no "going back" to Africa but that his journey is a discovery of a new culture and of new codes, of a new vision of fatherhood. The white myth of the master as a paternal figure is then contested by Nash as he progressively abandons the American myth of the father to embrace the African culture.

\section{The representations of motherhood in the novel: from movement to loss}

If fathers, both real and mythical, are proven ineffective in the novel, mothers do not necessarily receive more positive fictional representation. As stated by Eric Foner:

In a sense, slavery had imposed upon black men and women the rough "equality" of powerlessness. With freedom came developments that strengthened patriarchy within the black family and institutionalized the notion that men and women should inhabit separate spheres. (132)

Being a mother under slavery or becoming a mother in the context of war and racism in England in the 1940s is presented by Phillips as an impossible task. In her book entitled Mothering: Ideology, Experience and Agency, Patricia Hill Collins observes that "family links social hierarchies of gender, race and nation" (65), and women are at the core of this cell-like construction. Yet, in many postcolonial texts, motherhood is presented as a sacrificial crossing of human borders. In Crossing the River women prove incapable of recreating a proper family out of slavery and war; love - contrary to what the African father writes in the epilogue - is not powerful enough to overcome desertion and racism and eradicate the memory of loss.

"West" is Martha Randolph's narrative. Martha, sold into slavery alongside her brothers Nash and Travis (the three African children evoked in the prologue), ends up working on a plantation in Virginia. She is a direct victim of the peculiar institution. In this context, she develops a very peculiar bond - as it is born from slavery - with her daughter Eliza Mae, a bond forged out of suffering, resilience and abnegation. When her Master dies, Martha discovers that she and her family will be sold at auction (76-7). When Martha flees from Mr. Hoffman - after he explains to her that they are going to sell her back across the river (80) - she instantly finds herself turned from slave to fugitive slave. Phillips narrates this change in social condition as a "passage" - another crossing. Her experience of running away from her condition evokes Sethe's running away from the Sweet Home plantation in Morrison's Beloved - a shared experience of escaping which resonates within the extended "family" identified by Paul Gilroy as "the black Atlantic culture." What is implied by this concept is something new:

These ideas about nationality, ethnicity, authenticity, and cultural integrity are characteristically modern phenomena that have profound implications for cultural criticism and cultural history. They crystallized with the revolutionary transformations of the West at the end of the eighteenth and the beginning of the nineteenth centuries and involved novel typologies and modes of identification. (Gilroy 2) 
This vision - shared by Phillips - offers what Bénédicte Ledent calls "an alternative to binary absolutisms, whether ethnocentrism and nationalism on the one hand or pluralism and anti-essentialism on the other" (Caryl Phillips 125), and allows a creative and mobile re-reading of the history of the African diaspora. Movement and displacement are central to Gilroy's concept and are inscribed in Phillips's fiction.

As an example of the importance of movement and motherhood in the novel, Martha's obsession is focused on the idea of moving to the west to recover Eliza Mae ("Eliza May" is the representative female slave, as Phillips chooses for his character the name coined by Harriet Beecher Stowe for her own heroine in Uncle Tom's Cabin [1852]). She is the long-loved and sought-after daughter. She is Morrison's Beloved, a ghost and a hope. This ghostly hope is incarnated in the text by the word "Moma" (Phillips, 1993 77) that she cries when mother and daughter are separated by the auction, a desperate call for help. The answer to that call is silence. Martha knows words will not change her daughter's destiny and she wants her to be strong without her: "My Eliza Mae holds on to me but it will be to no avail. She will be a prime purchase. And on her own she stands a better chance of a fine family" (77). After the physical split occasioned by the auction, instead of answering, Martha moves west to try and find out if her daughter now lives in California.

Now that she is physically separated from her daughter, Martha has the strange conviction that she, too, must become part of the exodus that is heading west. For Martha, to head west means a literal "crossing of the river," but instead of the Ohio river the southern slaves crossed so as to escape from slavery and reach the north, she crosses the Missouri River and its borders to reach another kind of north: a symbolical cardinal point abolishing all other cardinal points (north and west being here mixed up), that is to say all human systems, particularly that of slavery. Martha believes that she must reinvent herself by running away from her past in order to re-discover her lost daughter in a completely different context, and this strategy is like "pioneering." It is radically different from Sethe's "rememory" process of reconstruction of the past by the acceptance of its painful return. ${ }^{4}$ More than a fugitive slave, Martha is a frontier woman whose plan is to re-conquer her own motherhood. Thus she joins her brother in his discovery of a "new world," as Nash likewise sees his journey back to Africa as "pioneering" (23). ${ }^{5}$ This journey west is a pathetic re-reading of history as Martha's only conquest is death, as pointed out by Catherine Lanone:

The journey is cold too, but instead of leaping on the ice, old arthritic Martha dies of exposure, of cold. [...] In Martha's case being sent back "across the river" (80) by the Hoffmans means being doomed to violence, and the only river that she may cross in the end is the Styx, the river of death. (62)

In slavery as in wartime, women and children are the first victims of dispersion and loss. In "Somewhere in England," Joyce experiences the loss of her son and learns to survive it. A slave to men (Len beats her) and to social convention (miscegenation is a sin in Britain in the 1940s), Joyce's whiteness is of no help to her. When she loses her second

4. Toni Morrison, Beloved. The word "rememory" is coined by Morrison, as is the word "disremember" (dis + remember), indicating the painful process of "remembering" as an amputation of one's old self to rebuild a new one, the Subject literally bumping into his own memories.

5. Before disappointment, Nash believes in his Master's ideal of Christianization of the lost "sheep" of Africa and of conquest of a virgin land and considers his "mission" as pioneering. 
The Destruction and Impossible Reconstruction of Family Links in Crossing the River by Caryl Phillips

husband Travis, the black American GI killed at war, she loses all her bearings. Her cross-cultural transgressive experience is another illustration of the plight of women. To conquer the illusion of freedom, the first thing she does is to re-construct imaginatively her relationship with her dead mother and here again, traveling to the dead mother is like traveling to the "lost" child for Martha, mother and daughter being in these inverted scenarios interchangeable. Movement seems to be presented as the solution whereas it actually leads to death and loss. If, when alive, Joyce's mother was often judgmental and harsh on her, Joyce rebuilds her love for her through memory and dream. Ironically and tragically enough, it is only after her mother's death that their relationship seems to improve: "Now that she was with her maker I had the feeling that she was listening to me. Which is more than she ever did when she had some breath in her body" (187).

The other common point developed with Martha's destiny is the similarity between the context of warfare in England and that of slavery in America: like slavery, warfare has the power to fracture and destroy families. In this section, there is a scene reminiscent of the slave auction scenes in Martha's narrative, when Joyce remembers the evacuee children (144) who had arrived in her village in the midst of World War II, wearing tags around their necks. Both women actually share a common destiny and a common doom. Joyce's position is interesting precisely because she seems to embody the synthesis of all the female representations in the novel: she suffers from a man's brutality, she is a mother to Greer, she is her mother's daughter, she is also psychologically separated from her mother by her father's death and by exterior circumstances over which she has no control.

But beyond these representations of motherhood and of a plight inscribed in the classical standards of feminine essentialism - having children being at the same time women's strongest and weakest point - Phillips opens up the space of fiction to a wider reflection about these pre-conceived gendered representations.

\section{Fiction as the place of sisterhood vs. "de-maternalization"6}

Movement and displacement are chosen by Martha as a delusional response to diaspora itself: she journeys through America to go back to her family but all she finds is homelessness. The only image she keeps of her daughter before dying at the end of the chapter is not a memory properly speaking but a dream, in which she mentally reconstructs her daughter's life in the west, imagining for her an honorable life with husband and children, a happy family life Martha is excluded from, as if her own unconscious refused to accept this prospect. Martha is excluded from the American dream of home and family as if there were no "location of culture" for diasporic peoples other than the "house of fiction," as Homi Bhabha explicitly states:

When historical visibility has faded, when the present tense of testimony loses its power to arrest, then the displacements of memory and the indirections of art offer us the image of our psychic survival. To live in the unhomely world, to find its ambivalences and ambiguities enacted in the house of fiction, or its sundering and splitting performed in the work of art, is also to affirm a profound desire for social solidarity. (18)

6. The term is coined by the author of the present article to represent the deprivation of the prerogatives traditionally attached to mothers: care, love and protection. 
Dream and imagination become feminine devices for a creative re-reading of the real and of history in the novel. While Hamilton and Nash appear more as victims of the concrete reality of history and live in the present rather than focusing on the future (business is business to Hamilton, even if he dreams of another life with his wife; and Africa is a new home to cope with for Nash even if he dreamt of another reality), the "strong" women of the novel - Martha and Joyce - radically re-invent their lives to the point of denial: Martha dreams the future and makes this dream a goal while Joyce tries to bury the past. The meta-language of dream is Martha's way out of a devastating reality she can no longer physically escape. The emphasis placed by the author on the relation existing between imagination and femininity in fiction is at the same time a way to re-install women in the realm of fiction - the "house of fiction" - and present them as "characters," but also, probably unconsciously, to place them on the margins of history, as they seem to be "acted upon" by men or determined by events. Fiction is thus a place where women's social powers and weaknesses are reflected through a variety of symbols and images, and are also transcended. Henry James's own perception of the "house of fiction" in The Art of the Novel, insists on the richness of interpretations fiction offers. The well-known passage from the Preface to The Portrait of a Lady contains the essence of James's conception of the novel:

The house of fiction has [...] not one window, but a million - a number of possible windows not to be reckoned, rather; every one of which has been pierced, or is still pierceable, in its vast front, by the need of the individual vision and by the pressure of the individual will. (46)

These "millions of windows" are seen by Phillips as means of using fiction so as to question preconceived definitions of gender and race. Joyce, Martha's white counterpart, appears to be like a fictional sister to Martha or a white and inverted version of her, which blurs even more the racial boundaries between the two women. They actually share the same father in the epilogue, where the African father seems to recognize Joyce as one of his lost children: "But my Joyce, and my other children, their voices hurt but determined, they will survive the hardships of the far bank" (235). When the woman appears at the end of "West" to help Martha, nothing indicates that she is white and yet everything, like the repeated image of the gloved hand, seems to imply it: "Perhaps this woman had bought her daughter?" (74)

Through his fictional reconstruction, Phillips allows his female characters to transcend the determinism of essentialism and appear as very resilient individuals. For instance, Martha is placed in the role of a pioneer in the West, a role which is usually associated to white males; the male black pioneers in the novel are also ironically given the roles of white pioneers conquering the West (whereas the historical myth of America's "Manifest destiny" does not identify black people as "conquerors"). As for Joyce, in the chapter "Somewhere in England," she has to experience a series of extreme hardships in order to ensure her own survival, hardships which are to some extent similar to Eliza Mae's. Not becoming a "real" mother will be the most traumatic one. Even if she is not exactly given the possibility of acting as she wishes, she is a rebel - a "'strong' northern female" as John McLeod puts it (17) - as she observes and comments upon the effects of war and uprooting on people and is presented as a very strong character, although she personally embodies vulnerability. Fiction is thus an open space - an "open text," to quote from Umberto Eco's The Role of the Reader: Explorations in the Semiotics of Texts 
The Destruction and Impossible Reconstruction of Family Links in Crossing the River by Caryl Phillips

(7) - where imagination redefines new borders and new codes and suggests ways of freeing oneself from social norms.

With Joyce, Phillips opens up his analyses of the doom of "de-maternalization" to all the women who have been in contact with Gilroy's "Black Atlantic." He thus creates a form of cultural sisterhood, a "Female Atlantic" to some extent. This "female Atlantic" is an expansion of Gilroy's vision of a purely masculine experience of the African diaspora and is constructed out of a symbolic perception of displacement and movement, separated from the real and historical experience of journey and voyage. As a matter of fact, the transoceanic voyage is usually presented in postcolonial diaspora theory as a male experience. Elizabeth DeLoughrey even points at Phillips's "patriarchal genealogy for the diasporic 'children' of the Americas" (218) in Crossing the River when the notion of "crossing" is dealt with: "Phillips' work evidences an overt consciousness of how women are positioned in the public/private and traveling/dwelling binary system, but his narrative framework often collapses back into a masculine paradigm" (217). DeLoughrey's analysis aims at underlining the contrasts existing between Phillips's evocation of a more feminized vision of migration when he deals with contemporary Caribbean diaspora (as in The Final Passage) and his representation of the African diaspora. She establishes a parallel with Gilroy's own masculine vision of the journey and sees it as a lineage involving the erasure of femininity:

The Black. Atlantic offers an engaging way to examine male migrants' negotiations of their national, ethnic and regional identities. However, its gender privilege is unmarked because the impact experienced by the wives, families and/or friends left behind by Frederick Douglass, Martin Delany, Richard Wright or James Baldwin is completely erased. (218)

If this analysis is accurate and relevant on a first level of reading, it seems to overlook the fascination Phillips has for dreams and nightmares, that is to say for imaginative extrapolation of the real. It thus seems to ignore the symbolic dimension of the concept of "crossing" in the novel. Women in Crossing the River cross the river in more different ways than Captain Hamilton, Edward Williams or Nash. Their "crossings" - to be taken as voyages here - are psychological, emotional, sentimental and sometimes terrestrial (for Martha of course but also for Joyce, who travels from town to village. It is particularly significant when she goes to town after the air-raid, or when she travels around with Len for their honeymoon) and the fact they are not "oceanic" does not make these displacements less formative and less trans-cultural. Imagination is their ship. Phillips narrates one of these "passages" in the call-and-response style of black sermons in "West" - a passage which is also reminiscent of Toni Morrison and reflects the role of women in the collective culture based on call and response emphasizing the fact that for his female characters journeying is more like pioneering than reaching the other bank: "For where, she was not sure (don't care where), being concerned only with heading west (going west), away from the big river (away from Hell), and avoiding nigger traders who would gladly sell her back over the border and into Missouri" (80). Although she is alone on her journey, Martha remains connected with "the many-tongued chorus of the common memory" evoked by Phillips and that Gilroy represents as "the Black. Atlantic" but she is a creative and poetic element, not a direct actor as she is mainly acted upon by circumstances. The fact that Martha does not reach her destination - chosen by DeLoughrey as an example of her failure (218) - whereas men are successful in their journeys as they apparently seem to reach ano- 
ther bank (literally), simply indicates that the aim and goal of women's displacements are different from men's, more interior, and private (more "domestic," to go back to Bourdieu's presentation of the female habitus). The vision of a subliminal sisterhood emanating from the African father's choice to make Joyce one of his children and thus Martha's sister, shows Phillips's capacity to redefine a "location" for women's common experience of transculturality and hybridity, a location which goes far beyond Gilroy's vision and expands the experience of voyaging to literature and fiction, that is to say to imagination. Martha's "masculinization" - her transformation into a pioneer - is also a way for Phillips to indicate that women do not necessarily correspond to their traditional social habitus and can be as strong as men, and have the power to conquer their own spaces of identification. If Williams's wife Amelia and Hamilton's wife seem to be trapped in gender roles, the situation is different for Martha and Joyce even if each of them also "serves" men (for Martha, in the restaurant or at the laundry, and for Joyce, as an obedient wife at first).

Like Martha with Eliza Mae, Joyce loses her mixed-blood son. Like her, she does not have the physical or mental strength to fight for him when someone comes to take him for adoption. Yet contrary to her, she does not spend her life looking for him but tries to forget about him and his dead father. This is clearly revealed in her 1963 diary entry, when Joyce records a visit by her son Greer, who was put up for adoption as a young child, and comes back to her eighteen years later to question her about his father. She then apologetically replies, "I don't even have a picture of him. I'm sorry, love. I destroyed everything. Letters, pictures, everything. When I met Alan. It seemed the right thing to do" (223, my emphasis), an argument Martha also develops: "On her own she stands a better chance for a better life; I want to tell her this, to encourage her to let go, but I have not the heart" (77). But Martha intimately knows her argument is an erroneous one (her "heart" tells her there is "no better life" for her daughter). Both women then appear at the same time as victims of circumstances and consider themselves as "bad mothers" (loss is a highly traumatic experience for each of them: Martha is obsessed with her daughter and Joyce with the "woman in the blue coat" who took her son).

Joyce's strength does not lie in her experience of motherhood and in her relationship with her son, but more certainly in her analytical capacities in observing her surroundings. Joyce's journey to reach a portion of "truth" is purely fictional, as she chooses to write her experience of loss and deprivation in an a-chronological diary, resisting time and history. Even if the status of Joyce's narrative can be considered ambivalent (is a-chronology really Joyce's choice or is it Phillips's?), what cannot be denied is the fact that Joyce has the artistic perception of a writer. By writing, Joyce actually testifies to her experience of cultural deterritorialization ${ }^{7}$ from conformism - the traditional life of a white British young woman - to nonconformism - the traumatic experience of the widowed mother of a mixed-blood child. Her embedded "house of fiction" - her diary - is a mirror to Phillips's, and she probably is the most original character in the novel as she is endowed with the strength of historical testimony.

7. This reference to Deleuze and Guattari's strategies of minorization in Mille Plateaux can be relevant in the present case as Joyce is minorized at the same time by her gender (she got divorced, then was widowed at the end of the war, and then got married again to Alan) and by her interracial experience, which puts her at the margins of society and literally deterritorializes her from social norms. 
The Destruction and Impossible Reconstruction of Family Links in Crossing the River by Caryl Phillips

\section{The representations of surrogacy in the novel: fiction as commitment}

If real parents cannot assume their roles and protect their children, then who can? In the slave quarters of the Southern plantations, family bonds were artificially and secretly recreated by slaves themselves so as to protect their offspring from the masters: the venerable members of the slave community were called "aunts" and "uncles" and played the part of real family members. In the same way, the novel explores the idea of surrogacy as the result of the various forms of dislocation undergone by the characters, but also as a way to fill up by fiction some of the gaps in historical memory. Surrogacy is a process of substitution endowed with the political strength of agency, typical of "minor literatures" (Deleuze, Minor Literature 16).

Logically enough, Nash is the surrogate son of Williams, the "fake father"; Martha also develops surrogate family bonds so as to try to survive. Lucy in "West" is the surrogate daughter Martha seems to choose for herself. This tie also, like all surrogate ones in the novel, is short-lived. It is rewarding but ultimately broken by life. Cross-cultural surrogate bonding seems doomed to fail in the novel. Only surrogate relationships within the same racial and cultural framework seem possible, even though they are also difficult and unsatisfactory. Following the same logic, the woman who saves Martha is the image of surrogate sisterhood or motherhood, but this is totally inadequate as the shelter she offers is icy and Martha only receives a drink of cold water. She is not loved by this mother in the same way Edward Williams does not love Nash as a surrogate father should do (even if he seems to be guilt-ridden at the end of the section and genuinely suffer from Nash's death) and he offers only a perverted version of fatherhood. The conclusion is that no surrogate links can replace real family bonds. Family cannot be re-invented, it exists or it does not, and Crossing the River is a novel about the loss of biological family. When the African father calls Joyce his daughter or when Joyce and Greer meet again, it is too late for happiness to exist. Clearly the power of surrogacy in the novel does not lie in the re-creation of artificial family links.

As with motherhood and fatherhood, surrogacy needs to be analyzed at a more hypotextual level, that of the subterranean encoded language of the imagination that Deleuze coined as "minor literature":

A minor literature is not the literature of a minor language but the literature a minority makes in a major language. But the primary characteristic of a minor literature involves all the ways in which the language is affected by a strong coefficient of deterritorialization. [...] The second characteristic of minor literatures is that everything in them is political. In "great" literatures, on the contrary, the question of the individual (familial, conjugal, etc.) tends to be connected to other, no less individual questions, and the social milieu serves as environment and background. (Minor Literature 16)

If to Morrison and to most African-American female writers "everything is political," to quote Deleuze, the situation is much more subtle and cryptic with Phillips. His own political commitment has to be decoded and actually becomes really "audible" at the end of the novel only. One first has to look for what Kathie Birat calls the "textual encoding of reality" (Literacy 93) in Phillips's novel so as to reach the profound message delivered by the author. This is particularly true with the treatment of origins and of Africa. Contrary to the novels written by Morrison on the same subject (and probably to establish some authorial distance with them), Phillips gives the "real" father - be he absent or flawed - pride of place in his novel, which is not without political conse- 
quences. Phillips clearly polarizes the notions of "dwelling" and "traveling" (to go back to DeLougrey's definitions) into quite neat gender roles: women/sisters do not travel oceans (while males do) and are more related to the domestic sphere of "dwelling," while males are more classically related to power and "travelling" the seas. This does not mean they are not brave. If Phillips does not easily distinguish between the personal and the political, which might explain his difficulty in dealing with women, he nevertheless shows a clear interest in Joyce, who in a sense discovers the nature of the political through her own experience of femininity. She fights against patriarchy and masculine domination by divorcing Len for example and is a dissident character. Nevertheless, her strength does not give her access to a proper "voice" at the end of the novel. In the epilogue, the Father calls for his children and says: "For two hundred and fifty years I have listened. To my Nash. My Martha. My Travis. Joyce. That was all he said..." (Phillips's emphasis, 236). Even if the final section of the book is narrated by Joyce rather than Travis, she repeats his pronouncing of her name (225) and the Father in the epilogue repeats her words so that it is Travis's voice that we can hear in this final chorus of voices.

It is not surprising then to notice that Africa - the land of the original home and domesticity - is re-gendered from motherland to fatherland: "Africa the dark land of our forefathers" (41). Dwelling is here masculinized. By making an African father speak instead of the mythical grandmother (as exemplified by Baby Suggs for example in Beloved), Phillips causes Africa to leave the private sphere of the inside, of the past and of the memory the diasporic characters want to go back to and be nurtured by, to become in the final scene of the novel a masculine universe resounding with voices. Voice becomes the agency that bridges the gaps between differences and allows a cultural survival, beyond the dark destinies of the main characters. The analogy between "ocean" and "voice" or "tongue" - the major bridge Phillips actually creates in his novel - is reaffirmed in 2004 by Mark Stein through his reference to silenced voices:

The metaphor of "an ocean" thus evokes the traumatic experience of the Middle Passage, but its vastness and depth also bespeak a wider predicament that this literal displacement entailed. Slavocracy aimed at silencing its slave population to preclude unrest and rebellion by impeding communication. (my emphasis, 60)

Survival is thus the return of sound (music) and song, the sound of formerly silenced voices - male voices in Phillips's novel - which express a new polyphonic post-diaspora culture. Not only are the descendents of the history of slavery visible, but they are also audible through art.

This re-gendering of Africa and of its voices - artistic voices forming a chorus - is an original one which finally creates a tension and a gap between the prominent feminine authorial figures of the African-American literary world (Toni Morrison, Alice Walker) and a more masculinized African-Caribbean literary sphere. By valorizing the father, Phillips puts the castrating threat of the Mother - the politically committed female artist maybe? - at a distance. As a matter of fact, this choice brings Phillips closer to Gilroy's "patriarchal genealogy" of The Black Atlantic, that is to say to the birth of a new culture of blackness where women are left behind (see DeLoughrey 217-18), and which is not just made accessible by the re-crossing of an ocean but also by the fictional creation of a polyphonic song composed of aggregated male voices. The masculine voice created by Phillips in the epilogue encompasses all the other diasporic voices of Africa in the novel and transcends the death of the Father announced through Nash's 
The Destruction and Impossible Reconstruction of Family Links in Crossing the River by Caryl Phillips

repeated "Father, why has thou forsaken me?" $(42,73)$ This choice deprives the novel of any kind of positive outcome as far as family is concerned despite the cry for love upon which it ends. Only women have the biological power to "re-produce" original family bonds. Fathers (men) have many powers - they can forgive, as Greer does when he comes back to Joyce - but not that original and primeval one, as is shown by the vision of the African father hoping for love at the very end of the novel.

Nevertheless, if family seems sacrificed, the ending of the novel opens the door to the possible reconstruction of a common multicultural memory, which becomes a substitute for family and actually "fills" the void left by history. The novel examines the role of cultural myths related to family and places women in situations which subvert the standards and codes related to family, ending on the presentation of an idealized vision of "brotherhood" eradicating women. This passage taken from the epilogue and paraphrasing Martin Luther King's famous speech emphasizes Phillips's choice: "I have listened to the voice that cried: I have a dream that one day on the hills of Georgia, the sons of former slaves and the sons of slave-owners will be able to sit down together at the table of brotherhood" (236). And this new outcome is what really matters to Phillips and what makes "his" difference, his political standpoint. The major substitute for the missing family is art and culture in the novel: "The real [...] in his texts must be seen both as the historical reality which takes shape within the texts and as that vanishing horizon of brute experience to which he opposes another more hopeful horizon, what he calls the "many tongued chorus of common memory" (Birat, Shameful 46).

The masculine and brotherly re-Africanized "hopeful horizon," based on songs and chants, which is presented by Phillips as the only future for the Black Atlantic is based on black vocal art. It is a re-gendered "nation" of Brothers. Phillips's frontiers between genders are original ones: they separate fathers, mothers, children, brothers and sisters, and not just men and women, and can be porous. Black and white sisters - the "Female Atlantic" - rebuild a world of love through imagination and creativity but fail to make it concrete and real; sisters cannot be mothers, they cannot be proper wives either (Joyce is a widow, Martha loses all the men she loves, Amelia and Hamilton's wife have no children and their husbands are far from them) but they share the same experiences of dispossession and a common sisterhood. All the female characters seem to have a place in that Phillipsian vision of sisterhood, even the white "wives" - other than Joyce - as they are both sacrificed to their husbands' passions: Amelia is actually erased by Phillips early in the narration and Mrs. Hamilton sacrificed to the sea: "I love you all the greater for this sacrifice," Hamilton writes (109).

As for male characters, the situation is different. White characters are excluded from the vision of a global brotherhood at the end of the novel, which clearly stigmatizes them. The chorus is made of black voices only; Williams cannot be a voice as he is made incapable of actually "talking" to Nash, his letters remaining dead to him ("this letter was uncovered by Edward's wife, Amelia, and not conveyed," 11) and Hamilton is a ghostly captain roaming the seas in search of his dead father and incapable of engaging in any kind of direct physical communication (to him people are numbers and words written in a logbook or in letters). On the other hand, in the epilogue, vocal black brothers - Phillips's own representation of the "Black Atlantic" - manage to rebuild a common culture of resistance. This political - and patriarchal - standpoint is similar 
to the 1970s affirmation of the Black community in America and gives a historical and committed dimension to the direct reference to Martin Luther King made at the very end of the text.

Anne Garrait-Bourrier

University of Clermont-Auvergne

\section{Works Cited}

BнавHA, Homi. The Location of Culture. London: Routledge, 1994.

BirAt, Kathie. "A Shameful Intercourse: Meaning and Signifying in Caryl Phillips's Novels of the Slave Trade." Réinventer le réel. Eds. Thomas Dutoit and Trevor Harris P.U. Tours, 1999. 33-47.

- . "Literacy and empathy in Caryl Phillips's Crossing the River." Traversée d'une oeuvre : Crossing the River de Caryl Phillips. Eds. Vanessa Guignery et Christian Gutleben. Spec. issue of Cycnos 32.1 (2016): 89-105.

Bourdieu, Pierre. Masculine Domination. Trans. Richard Nice. Stanford: Stanford UP, 2001. Trans. of La Domination masculine. Paris: Seuil, 1998.

-. Esquisse d'une théorie de la pratique. Paris: Seuil, 2000.

Davison, Carol Margaret. "Crisscrossing the River: An Interview with Caryl Phillips.” Ariel 25.4 (October 1994): 91-99.

Degler, Carl N. Neither Black Nor White: Slavery and Race Relations in Brazil and the United States. U of Wisconsin Press, 1971.

Deleuze, Gilles, and Félix Guattari. Mille Plateaux. Paris: Éditions de Minuit, 1980.

-. What is a Minor Literature?'Trans. Robert Brinkley. Mississippi Review 11.3 (Winter/Spring 1983): 13 33. Trans. of Kafka: Pour une littérature mineure. Paris: Éditions de Minuit, 1996.

DeLoughrey, Elizabeth. "Gendering the Oceanic Voyage: Trespassing the (Black) Atlantic and Caribbean." Thamyris 5.2 (Autumn 1998): 205-231.

Eco, Umberto. The Role of the Reader: Explorations in the Semiotics of Texts. Bloomington: Indiana UP, 1984.

Foner, Eric. Reconstruction: America's Unfinished Revolution, 1863-1877. New York: Perennial Classics, 1988.

Gilroy, Paul. The Blacke Atlantic, Modernity and Double Consciousness. New York: Verso, 1995.

Guignery, Vanessa, and Christian GutLeben. Traversée d'une oeuvre: Crossing the River de Caryl Phillips. Spec. issue of Cycnos 32.1 (2016).

Hill Collins, Patricia. Mothering: Ideology, Experience and Agency. New York: Routledge, 2004.

Jaggi, Maya. "CCrossing the River': Caryl Phillips talks to Maya Jaggi." Wasafiri 20 (Autumn1994): 2529.

James, Henry. The Art of the Novel. Introduction by poet and critic R. P. Blackmur. New York: Charles Scribner's Sons, 1934.

Kolchin, Peter. American Slavery: 1617- 1877. New York: Hill and Wang, 1993.

Lanone, Catherine. "Repetition and Reckoning in Crossing the River." Traversée d'une oeuvre: Crossing the River de Caryl Phillips. Ed. Vanessa Guignery and Christian Gutleben. Spec. issue of Cycnos 32.1 (2016).57-71.

Ledent, Bénédicte. Caryl Phillips. Manchester and New York: Manchester UP, 2002.

- " "Overlapping Territories, Intertwined Histories: Cross-Culturality in Caryl Phillips's Crossing the River." The Journal of Commonwealth Literature 30.1 (1995): 55-62.

McLeod, John. "English Somewheres: Caryl Phillips and the English North." Postcolonial Spaces. The Politics of Place in Contemporary Culture. Ed. Andrew Teverson and Sara Upstone. Basingstoke and New York: Palgrave Macmillan, 2011. 14-27.

Phillips, Caryl. Crossing the River. 1993. London: Vintage, 2006.

STEIN, Mark. Black British Literature: Novels of Transformation. Columbus: Ohio State UP, 2004.

Tannenbaum, Franck. Slave and Citizen: The Negro in the Americas. New York: Vintage, 1946. 